\title{
KOMBINASI ALGORITMA BRUTE FORCE DAN STEMMING PADA SISTEM PENCARIAN MASHDAR
}

\author{
Rozzi Kesuma Dinata ${ }^{1}$, Safwandi $^{2}$, Novia Hasdyna ${ }^{3}$, Rudi Mahendra ${ }^{4}$ \\ 1,2,4 Program Studi Teknik Informatika Universitas Malikussaleh \\ Jl. Kampus Unimal Bukit Indah, Blang Pulo, Lhokseumawe, Aceh, Indonesia \\ ${ }^{3}$ Program Studi Teknik Informatika Universitas Islam Kebangsaan Indonesia \\ Jl. Medan - Banda Aceh Sp. Alue Awe, Lhokseumawe, Aceh, Indonesia \\ ${ }^{1}$ rozzi@unimal.ac.id, ${ }^{2}$ safwandi@unimal.ac.id, ${ }^{3}$ noviahasdyna@gmail.com, ${ }^{4}$ rudimahend7@gmail.com
}

\begin{abstract}
Abstrak-Penelitian ini mengkombinasikan algoritma Brute Force dan Stemming pada sistem pencarian kata mashdar. Tujuan penelitian ini adalah untuk memudahkan pengguna dalam mencari kata dasar dari suatu kata beserta dengan perubahannya dengan berdasarkan tinjauan kata dasar kepada mashdar. Adapun data yang digunakan dalam penelitian ini diperoleh dari kitab Tashrif karangan Syeikh Hasan bin Ahmad sebanyak 50 data. Hasil penelitian dengan mengkombinasikan algoritma brute force dan stemming pada pencarian mashdar dengan sample pengujian sebanyak 15 kata maka diperoleh nilai akurasi sebanyak $78.9 \%$, precission $86.6 \%$, recall $84.6 \%$ dan specificity $66.6 \%$.
\end{abstract}

Kata Kunci- Kombinasi, Brute Force, Stemming, Mashdar, Akurasi

Abstract-In this study Brute Force and Stemming algorithms are combined in the mashdar word search system. The purpose of this study is to facilitate the user in finding the basic words of a word along with its changes based on the review of basic words to mashdar. The data used in this study were obtained from 50 books of Tashrif by Sheikh Hasan bin Ahmad. The results of the study by combining brute force and stemming algorithms in mashdar search with a test sample of 15 words obtained an accuracy value of $78.9 \%, 86.6 \%$ precission, $84.6 \%$ recall and $66.6 \%$ specificity.

Keywords - Combination, Brute Force, Stemming, Mashdar, Accuracy

\section{PENDAHULUAN}

Kebutuhan terhadap informasi semakin meningkat, sehingga semakin banyak informasi yang dibutuhkan untuk dapat diperoleh dengan cepat, informasi tersebut baik berupa teks atau berbentuk gambar yang kemudian disajikan sebagai suatu bentuk data [1]. Suatu teks biasanya memiliki imbuhan baik prefiks, infiks dan sufiks yang berguna untuk melengkapi suatu kata, dalam bahasa Arab juga memiliki afiks seperti bahasa Indonesia yang berpengaruh terdahap perubahan maknya dari kata tersebut. Maka perlu dilakukan pemotongan imbuhan dan mengembalikan suatu kata kepada kata dasar baik dengan tinjauan kata dasar dalam bentuk fi'il madhi ataupun mashdar, untuk lebih mudah memahami makna dari kata tersebut [2].

Salah satu algoritma yang digunakan untuk membantu teks mining adalah stemming[3]. Adapun roses stemming berfungsi untuk menemukan kata dasar dari sebuah kata dengan melakukan pemotongan imbuhan yang terdapat di awal (prefiks), di tengah (infiks) atau di akhir (sufiks) maka stemming digunakan untuk mengganti bentuk dari suatu kata menjadi kata dasar dengan menghilangkan imbuhan yang terdapat pada teks, dalam teks bahasa Arab imbuhan ini tidak produktif karena pemakaiannnya terbatas hanya pada kata-kata tertentu, pemakaian imbuhan hanya tertentu pada kalimat yang memiliki huruf illat (alif ('), waw(و), ya(ي)) di dalam suku kata tersebut karena adanya perubahan bentuk dengan sebab tashrif maka kata tersebut harus dikembalikan kepada kata dasar semula untuk lebih mudah melakukan pencocokan dengan teks pada kamus di database [4]

Pada penelitian ini penulis mengkombinasikan algoritma brute force dan stemming pada sistem pencarian masahdar, untuk memudahkan masyarakat dalam mencari kata dasar dari suatu kata beserta dengan perubahannya dengan berdasarkan tinjauan kata dasar menjadi mashdar. Penelitian ini juga menganalisis nilai akurasi dari hasil kombinasi algoritma brute force dan steeming, berupa akurasi, precission, dan recall. 


\section{TINJAUAN PUSTAKA}

\section{A. Teks Mining}

Dalam melakukan klasifikasi dokumen tekstual, biasanya digunakan teks mining. Dokumen-dokumen tersebut akan dilakukan proses pengklasifikasian Page | 274 sesuai dengan topic dokumen. Dengan teks mining suatu artikel dapat juga diketahui jenis kategorinya. Analisis dan pencocokan basis data kata kunci dengan kata-kata yang mewakili isi dari artikel. Adanya teks mining dapat membantu melakukan pengelompokkan suatu dokumen dengan waktu yang singkat [5].

\section{B. Algoritma Brute Force}

Sebuah konsep yang di dasarkan pada pernyataan masalah secara langsung (straightforward) yang digunakan sebagai solusi untuk pemecahan masalah penyataan kalimat disebut dengan Brute force. Algoritma brute force memecahkan masalah dengan sangat sederhana, langsung dan dengan cara yang jelas (obvious way) [6].

\section{Stemming}

Stemming adalah suatu proses untuk menemukan kata dasar dari sebuah kata, dengan menghilangkan semua imbuhan (affixes) baik yang terdiri dari sisipan (infixes), awalan (prefixes), akhiran (suffixes) dan confixes (kombinasi dari awalan dan akhiran) pada kata turunan. Penggunaan Stemming biasanya digunakan untuk mengganti atau merangkai bentuk dari suatu kata menjadi kata dasar dari sebuah kata tersebut yang sesuai dengan struktur morfologi bahasa Indonesia yang baik dan benar. Imbuhan-imbuhan yang melekat pada suatu kata harus dihilangkan untuk mengubah bentuk kata tersebut menjadi bentuk kata dasarnya [7].

\section{String matching}

Proses pencarian semua kemunculan query yang selanjutnya disebut pattern ke dalam string yang lebih panjang atau teks merupakan String Matching. String matching dibagi menjadi dua, yakni exact matching dan heuristic atau statistical matching. Penggunaan exact matching sendiri adalah untuk menemukan pattern yang berasal dari satu teks. Contoh pencarian exact matching adalah pencarian kata "pelajar" dalam kalimat "saya seorang pelajar" atau "saya seorang siswa". Sistem akan memberikan dan menampilkan hasil bahwa kalimat pertama mengandung kata "pelajar", sedangkan kalimat kedua tidak, meskipun kenyataannya pelajar dan siswa adalah kata yang bersinonim [8].

\section{METODOLOGI PENELITIAN}

Adapun alur penelitian ini dapat dilihat pada diagram alir penelitian berikut.

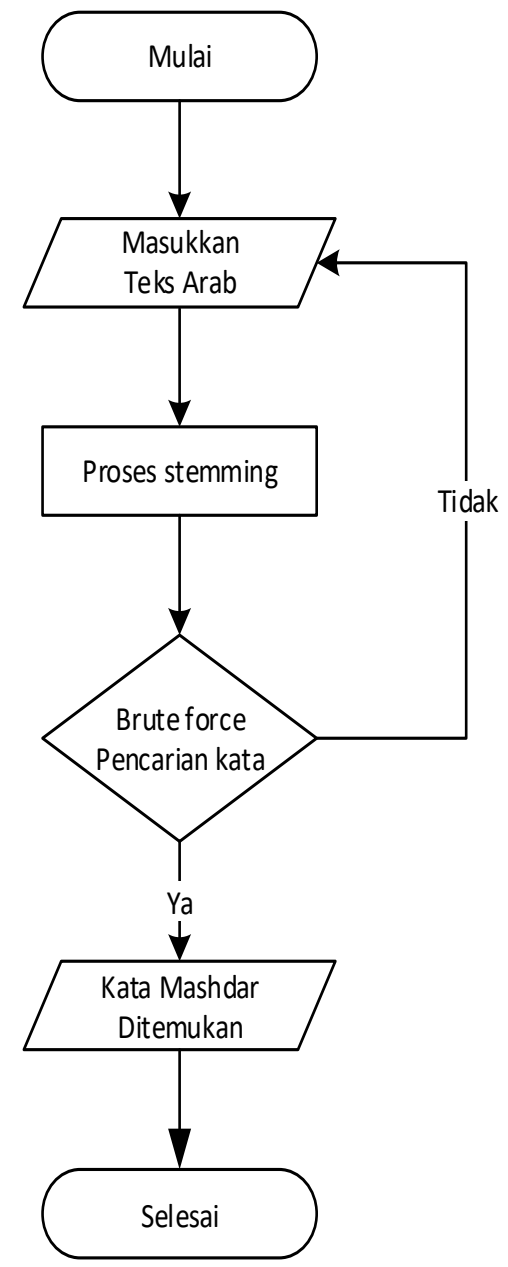

Gbr 1. Flowchart proses stemming dan brute force

\section{HASIL DAN PEMBAHASAN}

A. Manajemen Basis Model

1. Use Case Diagram
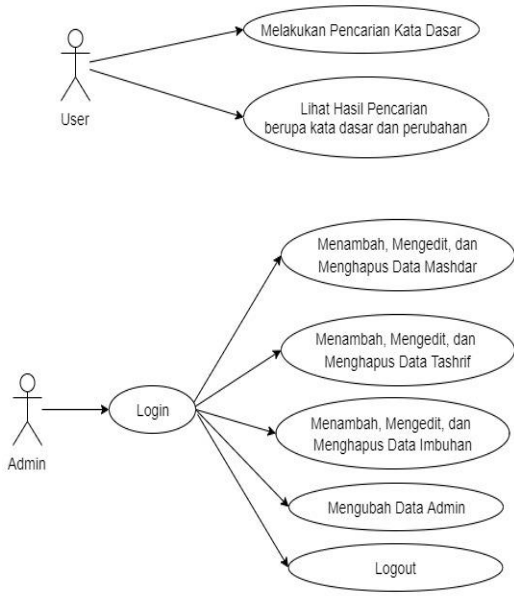

Gbr 2. Use Case Diagram

2. Sequence Diagram

a. Sequence diagram login 


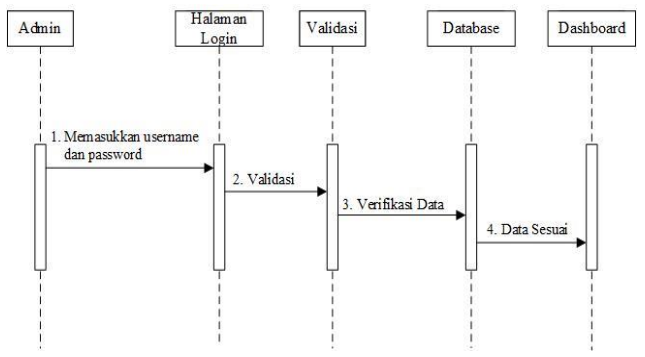

Gbr 3. sequence diagram login

b. Sequence diagram tambah mashdar

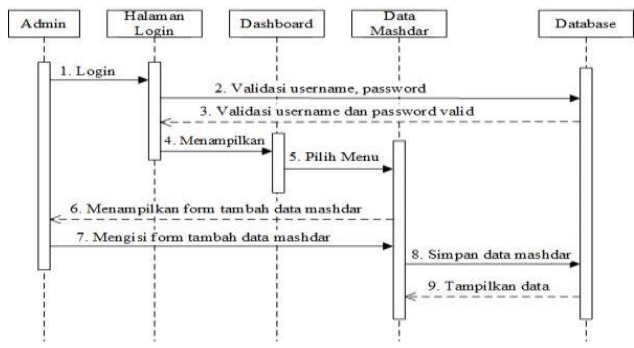

Gbr 4. Sequence diagram mashdar

c. Sequencediagram tambah tashrif

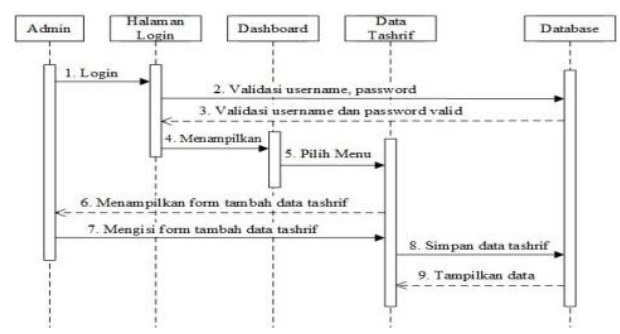

Gbr 5. Sequence diagram tashrif

d. Sequencediagram tambah imbuhan

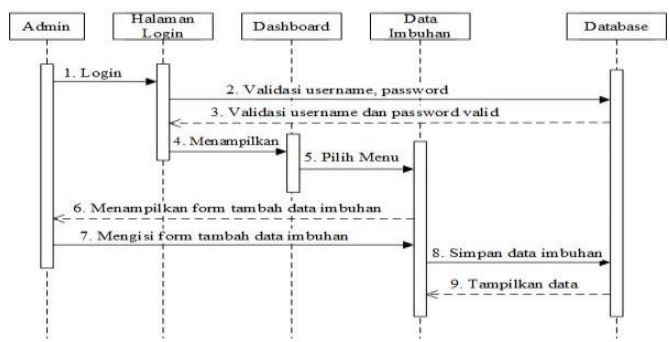

Gbr 6. Sequence diagram imbuhan

e. Sequencediagramproses

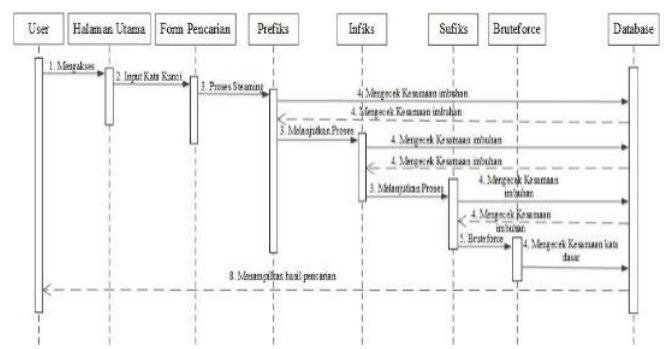

Gbr 7. Sequence diagram proses
3. Activity Diagram

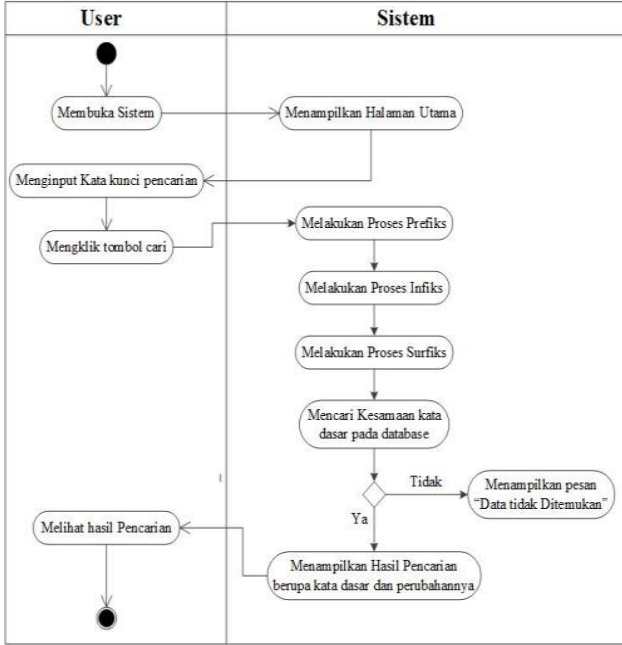

Gbr 8. Activity diagram

B. ManajemenBasis Data

1.Tabel_Admin

TABEL I

ADMIN

\begin{tabular}{|c|c|c|c|c|}
\hline No & Nama & Type & Width & Keterangan \\
\hline 1 & admin_id & Int & 10 & Primary key \\
\hline 2 & username & Varchar & 30 & Username \\
\hline 3 & password & Varchar & 30 & Password \\
\hline
\end{tabular}

\section{Tabel_Mashdar}

TABEL II

TABEL MASHDAR

\begin{tabular}{|c|c|c|c|c|}
\hline No & Nama & Type & Width & Keterangan \\
\hline 1 & Id_mashdar & Int & 10 & Primary key \\
\hline 2 & mashdar & Varchar & 30 & Kata dasar \\
\hline
\end{tabular}

3. Tabel_Tashrif

TABEL III

TABEL TASHRIF

\begin{tabular}{|c|c|c|c|c|}
\hline No & Nama & Type & $\begin{array}{c}\text { Widt } \\
\text { h }\end{array}$ & Keterangan \\
\hline 1 & id_tsh & Int & 10 & Primary key \\
\hline 2 & tsh_madhi & Varchar & 50 & Perubahan kata \\
\hline 3 & tsh_mudhari & Varchar & 50 & Perubahan kata \\
\hline 4 & tsh_mashdar & Varchar & 50 & Kata dasar \\
\hline 5 & tsh_ism_fail & Varchar & 50 & Perubahan kata \\
\hline 6 & tsh_ism_maful & Varchar & 50 & Perubahan kata \\
\hline 7 & tsh_amr & Varchar & 50 & Perubahan kata \\
\hline 8 & tsh_nahi & Varchar & 50 & Perubahan kata \\
\hline 9 & tsh_ism_zaman & Varchar & 50 & Perubahan kata \\
\hline 10 & tsh_ism_makan & Varchar & 50 & Perubahan kata \\
\hline 11 & tsh_ism_alat & Varchar & 50 & Perubahan kata \\
\hline
\end{tabular}

\section{Tabel Imbuhan}

TABEL V

TABEL IMBUHAN

\begin{tabular}{|c|c|c|c|c|}
\hline No & Nama & Type & Width & Keterangan \\
\hline 1 & Id_imbuhan & Int & 10 & Primary key \\
\hline 2 & prefiks & Varchar & 20 & Imbuhan diawal \\
\hline 3 & infiks & Varchar & 20 & Imbuhan ditengah \\
\hline & sufiks & Varchar & 20 & Imbuhan diakhir \\
\hline
\end{tabular}




\section{Proses Kombinasi Brute Force dan Stemming}

Pada pengujian ini penulis menggambarkan bagaimana proses pemotongan dan pencarian kata mashdar dengan menampilkan source code program beserta dengan penjelasannya, sebagai berikut:

1. Proses pemotongan prefiks

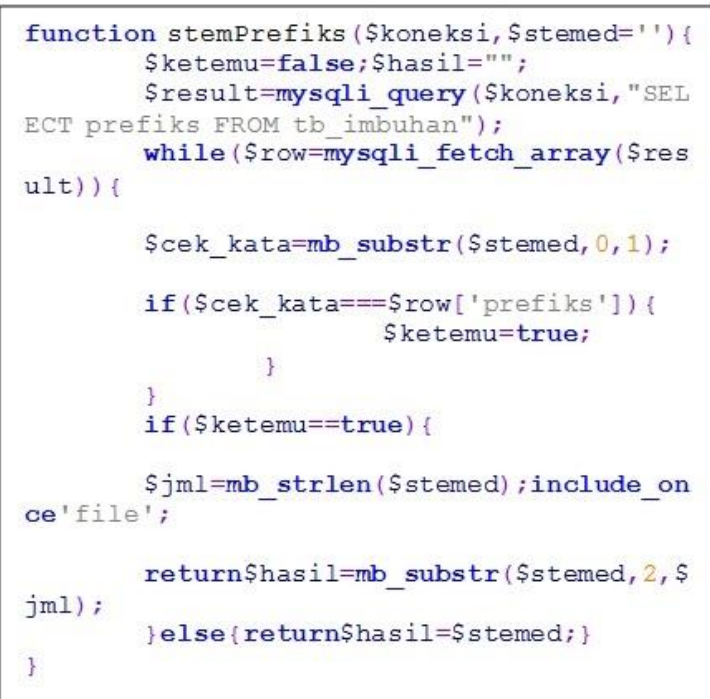

Gbr 9. Pemotongan prefiks

Pada gambar 2 diatas merupakan fungsi stem prefiks yang membutuhkan 2 parameter.

2. Proses pemotongan infiks

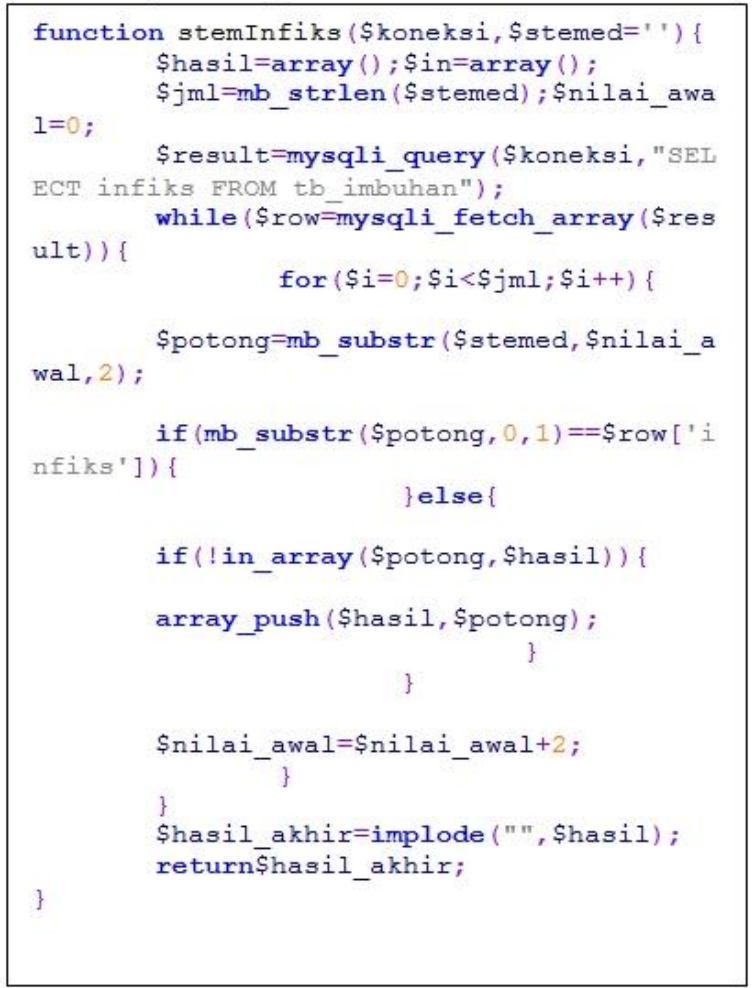

Gbr 10. Pemotongan infiks

Pada gambar 3 diatas menunjukkan fungsi stem infiks yang membutuhkan 2 parameter yaitu variabel koneksi ke database dan variabel stemed, inisialisasi variabel hasil dengan nilai array kosong dan variabel in dengan array kosong juga lalu isi variabel jml dengan panjang dari variabel stemmed, variabel nilai_awal dengan variabel 0 dan isi variabel result dengan nilai dari database pada field infiks.

3. Proses pemotongan sufiks

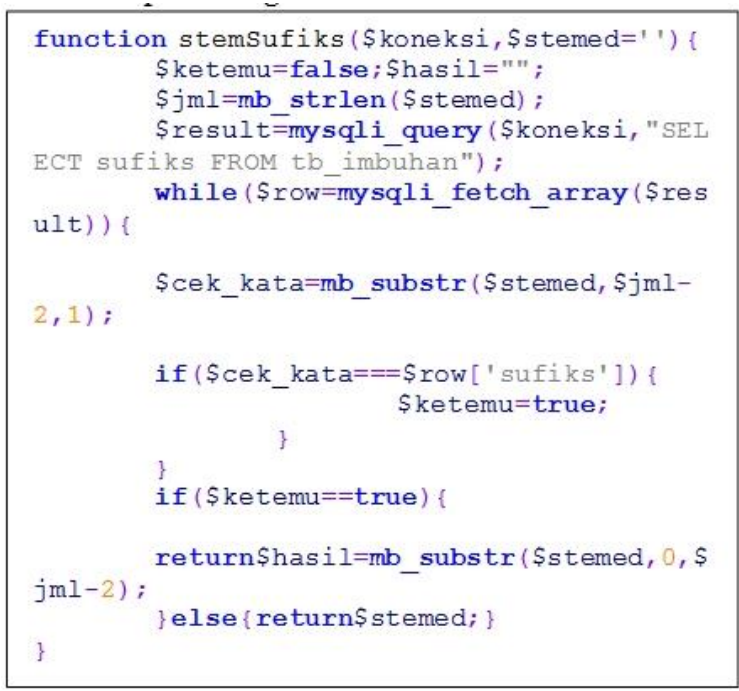

Gbr 11. Pemotongan sufiks

Pada gambar 4.26 diatas merupakan fungsi stem sufiks yang membutuhkan 2 parameter yaitu variabel koneksi ke database dan variabel stemed kemudian inisialisasi variabel ketemu dengan false dan Variabel hasil dengan string kosong.

4. Proses pencarian brute force

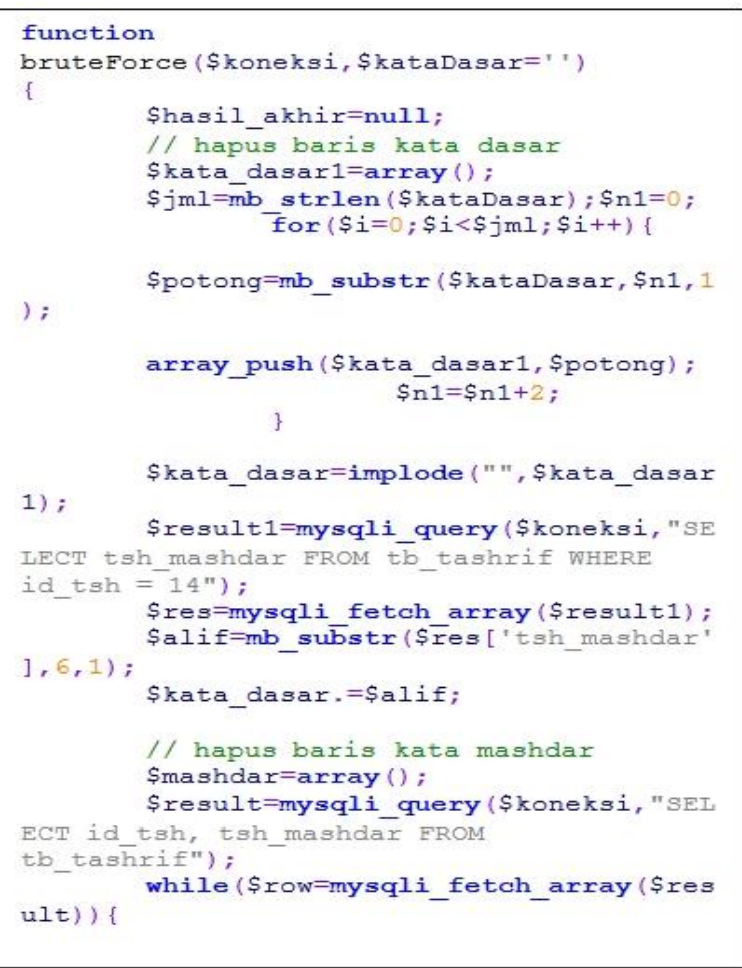




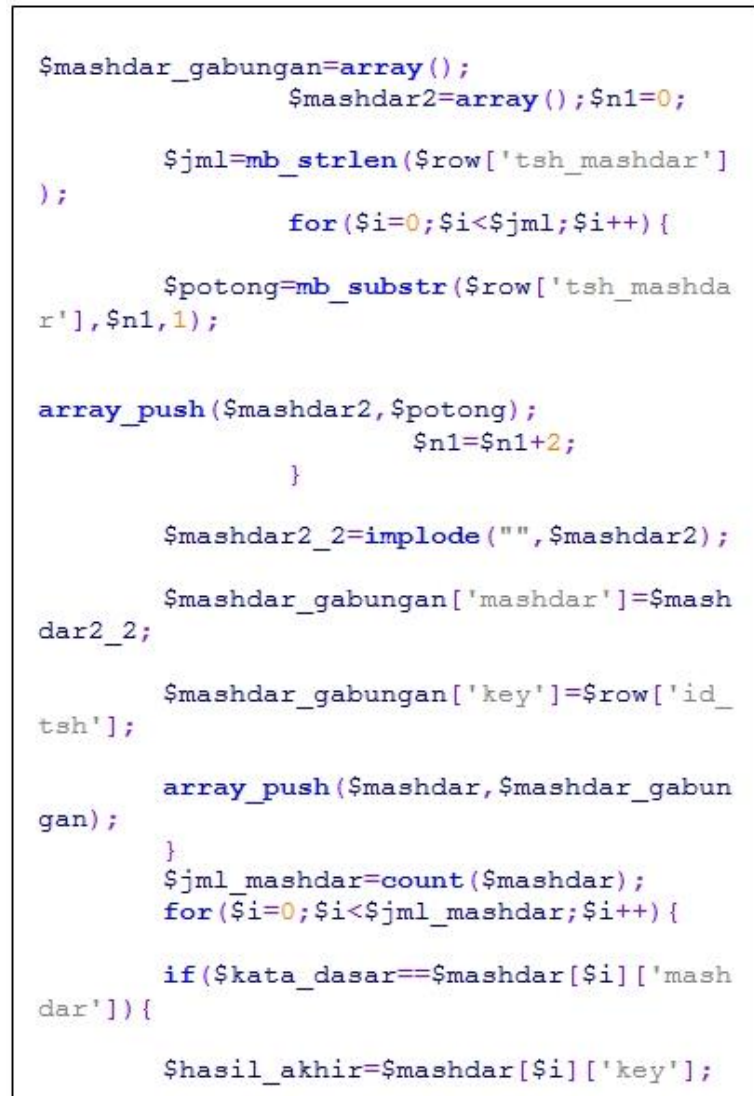

Gbr 12. Pencarian brute force

\section{Sampel Data Tashrif}

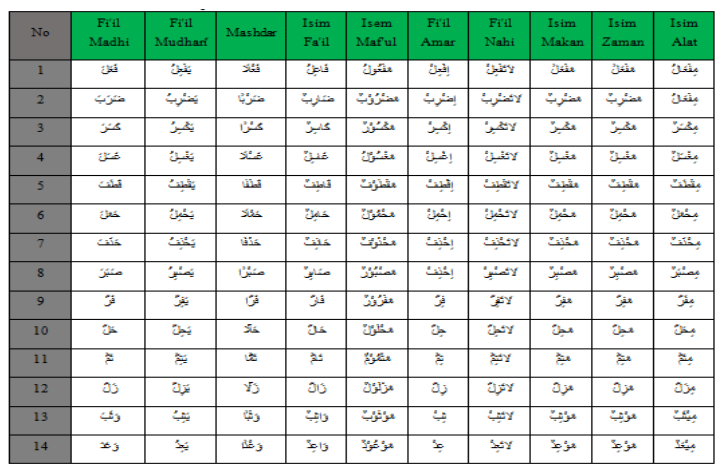

Gbr 13. Sampel Data Tashrif

\section{E. Implementasi Sistem}

Adapun tampilan system kombinasi brute force dan masdar adalah sebagai berikut:

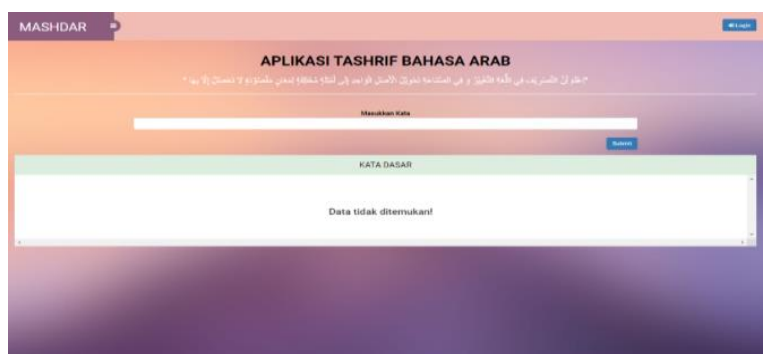

Gbr 14.Tampilan Menu Utama

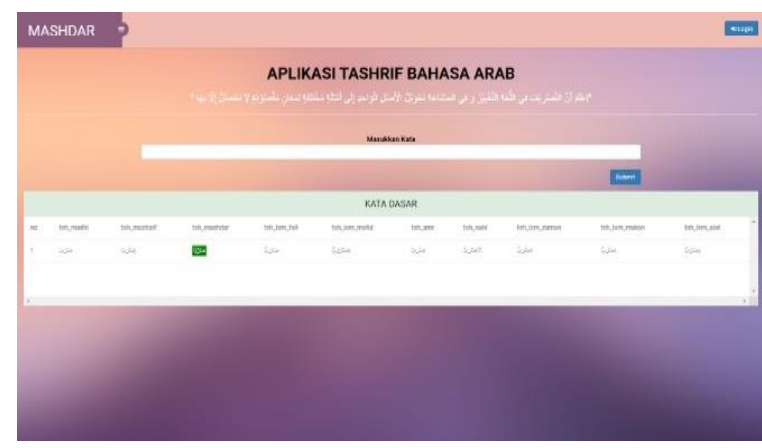

Gbr 15. Hasil pencarian

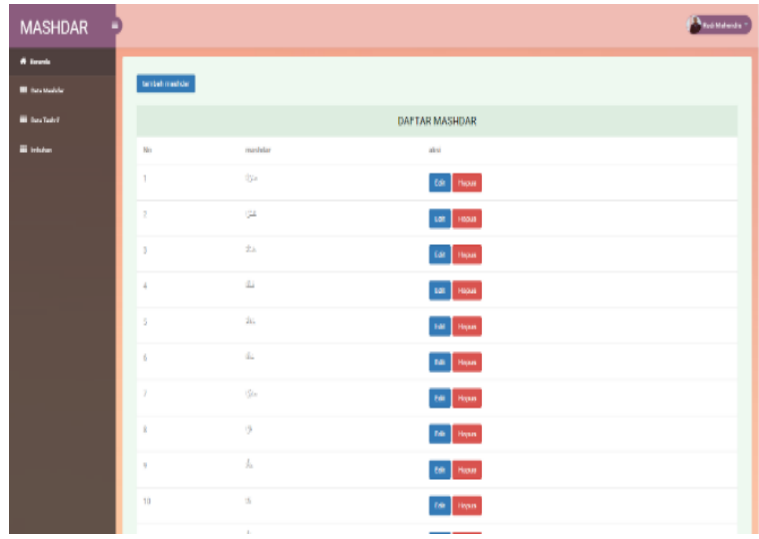

Gbr 16. Tambah Data Masdar

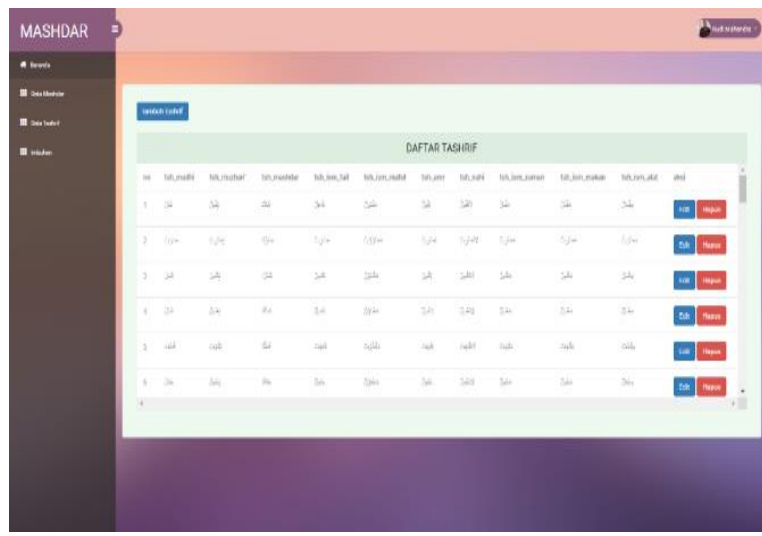

Gbr 17. Halaman Tashrif

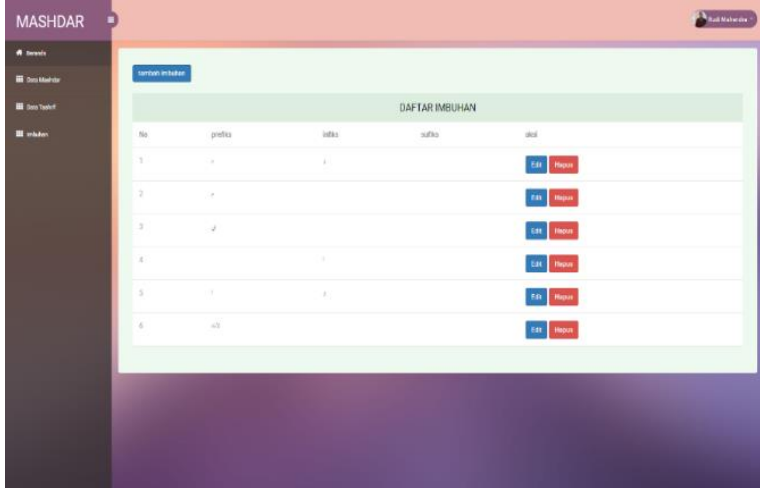

Gbr 18. Halaman imbuhan 
F. Pengujian Sistem

Hasil pengujian performa adalah:

a. Performa akurasi

$$
\begin{aligned}
\text { Akurasi }= & \frac{(\mathrm{TP}+\mathrm{TN})}{(\mathrm{TP}+\mathrm{FP}+\mathrm{FN}+\mathrm{TN})} \\
& =\frac{(11+4)}{(11+2+2+4)} \\
& =\frac{(11+4)}{19}=\frac{15}{19} \\
& =0.789 \times 100 \% \\
& =78.9 \%
\end{aligned}
$$

b. Performa precission

$$
\begin{aligned}
\text { Precission } & =\frac{\mathrm{TP}}{(\mathrm{TP}+\mathrm{FP})} \\
& =\frac{11}{(11+2)}=\frac{11}{13} \\
& =0.846 \times 100 \%=84.6 \%
\end{aligned}
$$

c. Performa recall

$$
\begin{aligned}
\text { Recall } & =\frac{\mathrm{TP}}{(\mathrm{TP}+\mathrm{FN})} \\
& =\frac{11}{(11+2)}=\frac{11}{13} \\
& =0.846 \times 100 \%=84.6 \%
\end{aligned}
$$

d. Performa specificity

$$
\begin{aligned}
\text { Specificity } & =\frac{\mathrm{TN}}{(\mathrm{TN}+\mathrm{FP})} \\
& =\frac{4}{(4+2)}=\frac{4}{6} \\
& =0.666 \times 100 \%=66.6 \%
\end{aligned}
$$

\section{PENUTUP}

Hasil dari kombinasi Algoritma brute force dan stemming diimplementasikan untuk mencari tingkat akurasi dalam pencarian kata mashdar beserta dengan perubahannya, dengan menggunakankan data uji sebanyak 50 kata dalam teks Arab, sehingga akurasi yang diperoleh dari beberapa teks yang diambil sebagai sample pengujian mempunyai hasil akurasi $78.9 \%$, precission $84.6 \%$, recall $84.6 \%$ dan specificity $66.6 \%$.

\section{REFERENSI}

[1] Putri, E. K., \& Setiadi, T. (2014). Penerapan Text Mining Pada Sistem Klasifikasi Email Spam Menggunakan Naive Bayes. Jurnal Sarjana Teknik Informatika, 73-83.

[2] Pratita, H. S. (2016). Analisa Brute Force Attack menggunakan Scanning Aplikasi pada HTTP Attack. 2016.

[3] Al Ajeeli, A. T. (2016). An Intelligent Framework for Natural Language Stems Processing. Global Journal of Computer Science and Technology, 16(1), 22-38.

[4] Bin Ahmad Al-Ahdal, M. (2011). Al Kawakib Ad-Durrivah. Marocco: Haramain.

[5] Herwijayanti, B., Ratnawati, D. E., \& Muflikhah, L. (2018). Klasifikasi Berita Online Dengan Menggunakan Pembobotan TF-IDF dan Cosine Similarity. Pengembangan Teknologi Informasi dan Komputer e-ISSN, 2548, 964X.
[6] Pratiwi, H., Arfyanti, I., \& Kurniawan, D. (2016). Implementasi Algoritma Brute Force Dalam Aplikasi Kamus Istilah Kesehatan. jurnal ilmiah teknologi informasi terapan, 119-125.

[7] Mei M.L, A. R. (2015). Studi Perbandingan Akurasi Light Stemming dan Khoja Stemming Pada Fi'il Madhi dan Mashdar. Malang: Universitas Islam Negeri Maulana Malik Ibrahim.

[8] Mesran. (2014). Implementasi Algoritma Brute Force Dalam Pencarian Data Katalog Buku Perpustakaan. JurnalMajalah Ilmiah Informasi dan Teknologi Ilmiah (INTI), 100-104. 